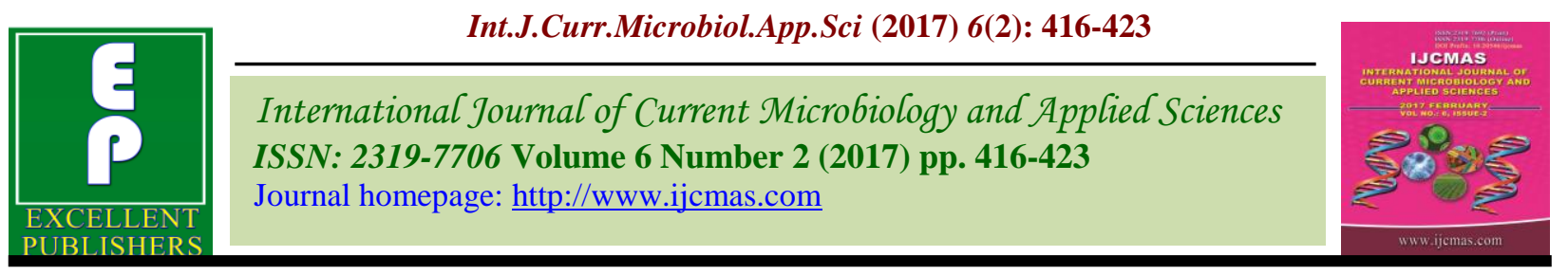

Original Research Article

http://dx.doi.org/10.20546/ijcmas.2017.602.046

\title{
Performance of Newer Insecticidal Treatments on Natural Enemies and Yield Contributing Factors in Sorghum
}

\author{
A.B. Birangal*, K.S. Pagire, B.M. Wagh and Dipali Thakare \\ Sorghum Research Farm, Mahatma Phule Krishi Vidhyapeeth, Rahuri (M.S.), India \\ *Corresponding author
}

A B S T R A C T

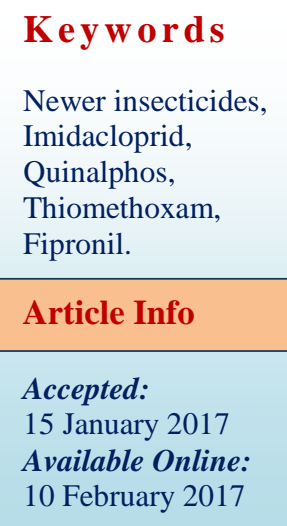

\section{Introduction}

Sorghum (Sorghum bicolor L. Moench) is widely grown cereal crop throughout the world. It is being grown in tropical and sub tropical regions. It is a chief source of palatable fodder for cattle in many parts of the world. In India, sorghum ranks third in area and production after rice and wheat. The crop accounts nearly 52 per cent area and 63 per cent production under millets with an area of 11.13 million hectares and production of 11.62 million tones. Maharashtra, Karnataka, Andhra Pradesh, Gujarat, Tamil Nadu and Madhya Pradesh are the major sorghum growing states (Anonymous, 2012). Sorghum grains contains about 10-12 per cent protein, 3 per cent fat and 70 per cent carbohydrates.
The incidence of sorghum shoot fly is greater in late sown crop in rainy and post rainy seasons in India. Maximum yield losses of 75.6 per cent grain and 68.6 per cent in fodder have been reported by Pawar et al., (1984). The shoot fly is one of the major constraints in the production of grain and fodder, which infests sorghum crop to the extent of 97 per cent, (Kandalkar and Narkhede, 1989). Lower yield of sorghum have been attributed to a number of factors, among them the loss caused by the insect pests has been considered as one of the important factors for lower production. There are nearly 150 insects species have been reported as pests on sorghum in different agro-ecosystem (Reddy 
and Davies, 1979). Among that sorghum shoot fly, Atherigono soccata Rondani (Order - Diptera, Family - Muscidae) is the most destructive one and cause severe damage in the early i.e. seedling stage and last up to 4 weeks causing severe reduction in plant population thereby causing heavy yield losses. While controlling sorghum pests it is important to study the newer insecticidal effect on natural enemies and yield contributing factors in sorghum.

\section{Materials and Methods}

The field experiment was conducted at sorghum research farm, Mahatma Phule Krishi Vidhyapeeth, Rahuri during rabi season 2013-14. The trial was laid out in a randomized block design (RBD) with three replications. The variety "Phule Vasudha" was sown at spacing $45 \times 15 \mathrm{~cm}$. The required quantities of sorghum seeds and insecticides were poured in polythene bag; few drops of water were sprinkled on the mixture of seed and insecticides. Open end of the bag was folded with one hand, then the bag was rotated with both hands keeping one hand at the bottom of bag until seed were coated well with insecticides and plastic bag surface become clear. The seeds were kept open overnight for drying. The imidacloprid $48 \%$ FS was applied to seed at 5 and $10 \mathrm{ml} / \mathrm{kg}$ seed. The treated seeds used for sowing by dibbling. Spraying solution prepared with different insecticides viz., quinalphos $25 \%$ EC $2 \mathrm{ml} / 1$, thiomethoxam $25 \% \mathrm{WG}$ at $0.4 \mathrm{~g} / 1$, imidacloprid $17.8 \% \mathrm{SL}$ at $0.4 \mathrm{ml} / 1$, fipronil $5 \% \mathrm{SC}$ at $1.5 \mathrm{ml} / \mathrm{l}$ and azadirachtin 3000 PPM at $5 \mathrm{ml} / \mathrm{l}$ and spraying was carried out with knapsack sprayer. Two sprays given, first on $10^{\text {th }}$ and second on $20^{\text {th }}$ day after emergence of seedling to test the effect of insecticides on natural enemies, yield of sorghum, plant height and incremental cost benefit ratio. The observation on plant height was taken as height of randomly selected five plants in each plot was recorded on $21^{\text {st }}, 28^{\text {th }}$ day after emergence and at the time of harvest. The observation on grain yield was taken as ear heads harvested after the crop maturity and threshed separately replication wise for each treatment and to record grain weight $(\mathrm{kg} / \mathrm{plot})$. Mean yield of respective treatments converted to quintal per hectare. The observation on fodder yield taken as fodder was also harvested separately replication wise for each treatment and mean fodder yield of respective treatments were converted to quintal per hectare and observation on natural enemies were taken as the data on the population of the natural enemies i.e. predatory Coccinellids (Coleoptera) and Crossopalpus sp. (Diptera) per plot observed in different treatments recorded on $24^{\text {th }}$ day after emergence of seedling. Similarly, the natural enemies emerged from the dead hearts recorded in laboratory. The dead hearts of sorghum from experimental field of untreated plot were uprooted and kept in plastic bowl covered with muslin cloth lid. The natural enemies emerged from dead hearts were observed 1215 day after the uprooting the dead hearts plants. These natural enemies were preserved in $70 \%$ alcohol and were sent for identification to Division of Entomology, IARI, New Delhi.

\section{Results and Discussion}

\section{Effect of different insecticidal treatments on yield contributing parameter like plant height}

The data on the plant heights in table 1 at $21^{\text {st }}$ DAE there were significant differences among the treatments in respect of plant height. The maximum plant height recorded in plots treated with seed treatment of imidacloprid $48 \% \quad \mathrm{FS}$ at $10 \mathrm{ml} / \mathrm{kg}$ seed followed by spray of quinalphos $25 \%$ EC at $2 \mathrm{ml} / 1(52.17 \mathrm{~cm})$, imidacloprid $48 \% \mathrm{FS}$ at 10 $\mathrm{ml} / \mathrm{kg}$ seed $(51.67 \mathrm{~cm})$, imidacloprid $48 \% \mathrm{FS}$ at $5 \mathrm{ml} / \mathrm{kg}$ seed followed by spray of 
quinalphos $25 \% \mathrm{EC}$ at $2 \mathrm{ml} / 1(50.67 \mathrm{~cm})$ and imidacloprid $48 \%$ FS at $5 \mathrm{ml} / \mathrm{kg}$ seed $(49.17$ $\mathrm{cm})$, which were at par with each other and significantly superior over rest of the treatments followed by quinalphos $25 \% \mathrm{EC}$ at $2 \mathrm{ml} / \mathrm{l}(44.17 \mathrm{~cm})$ and thiomethoxam $25 \%$ WG at $0.4 \mathrm{~g} / 1(43.63 \mathrm{~cm})$, which were at par with each other. All the above treatments recorded higher plant height over untreated control $(29.33 \mathrm{~cm})$ (Table 1). At $28^{\text {th }}$ DAE all the insecticidal treatments $28^{\text {th }}$ day after emergence recorded significantly higher plant height over untreated control. The maximum plant height was recorded in the plots treated with seed treatment of imidacloprid $48 \% \mathrm{FS}$ at $10 \mathrm{ml} / \mathrm{kg}$ seed followed by spray of quinalphos $25 \% \mathrm{EC}$ at $2 \mathrm{ml} / 1(60.33 \mathrm{~cm})$, imidacloprid $48 \% \mathrm{FS}$ at $10 \mathrm{ml} / \mathrm{kg}$ seed $(59.83$ $\mathrm{cm}$ ), imidacloprid $48 \% \mathrm{FS}$ at $5 \mathrm{ml} / \mathrm{kg}$ seed followed by spray of quinalphos $25 \% \mathrm{EC}$ at 2 $\mathrm{ml} / 1(57.17 \mathrm{~cm})$ and imidacloprid $48 \% \mathrm{FS}$ at 5 $\mathrm{ml} / \mathrm{kg}$ seed $(56.33 \mathrm{~cm})$, which were at par with each other and significantly superior over rest of the treatments (Table 1). At harvest the treatment with seed treatment of imidacloprid $48 \% \mathrm{FS}$ at $10 \mathrm{ml} / \mathrm{kg}$ seed followed by spray of quinalphos $25 \% \mathrm{EC}$ at $2 \mathrm{ml} / 1(208.67 \mathrm{~cm})$ was recorded significantly higher plant height over rest of the treatments. The next best treatment was seed treatment of imidacloprid $48 \% \mathrm{FS}$ at $5 \mathrm{ml} / \mathrm{kg}$ seed followed by spray of quinalphos $25 \% \mathrm{EC}$ at $2 \mathrm{ml} / \mathrm{l}(204.50 \mathrm{~cm})$. The rest of the treatments were significantly superior in plant height in the range of 195.83 to $180.83 \mathrm{~cm}$ over untreated control $(170.17 \mathrm{~cm})$. The rest of the treatments in their descending order were imidacloprid $48 \% \mathrm{FS}$ at $10 \mathrm{ml} / \mathrm{kg}$ seed (195.67 cm), imidacloprid 48\% FS at $5 \mathrm{ml} / \mathrm{kg}$ seed $(194.83 \mathrm{~cm})$, quinalphos $25 \% \mathrm{EC}$ at 2 $\mathrm{ml} / 1(193.17 \mathrm{~cm})$ and thiamethoxam $25 \% \mathrm{WG}$ at $0.4 \mathrm{~g} / 1(192.67 \mathrm{~cm})$, which were at par with each other. The minimum plant height $(170.17 \mathrm{~cm})$ recorded in untreated control (Table 1). These present findings are in agreement with the results of Patil (1993) who reported that seed treatment with imidacloprid
70 WS increased shoot and root length of sorghum seedlings.

\section{Effect of different insecticidal treatments on yield of sorghum}

Grain and fodder yield influenced by different insecticidal treatments are presented in table 2 . The highest grain yield was obtained in the plot treated with seed treatment of imidacloprid $48 \%$ FS at $10 \mathrm{ml} / \mathrm{kg}$ seed followed by spray of quinalphos $25 \%$ EC at 2 $\mathrm{ml} / \mathrm{l}$ (34.61 q/ha), which was superior over rest of the treatments. The next best treatment was imidacloprid $48 \% \mathrm{FS}$ at $5 \mathrm{ml} / \mathrm{kg}$ seed followed by spray of quinalphos $25 \% \mathrm{EC}$ at 2 $\mathrm{ml} / \mathrm{l}(32.43 \mathrm{q} / \mathrm{ha})$ and was significantly superior over rest of the treatments. The rest of the treatments also recorded significantly higher grain yield over untreated control (23.37 q/ha).The treatments in their descending order of grain yield were imidacloprid $48 \% \mathrm{FS}$ at $10 \mathrm{ml} / \mathrm{kg}$ seed $(30.15$ $\mathrm{q} / \mathrm{ha}$ ), imidacloprid $48 \% \mathrm{FS}$ at $5 \mathrm{ml} / \mathrm{kg}$ seed (29.21 q/ha), quinalphos $25 \% \mathrm{EC}$ at $2 \mathrm{ml} / 1$ (28.77 q/ha) and thiamethoxam 25\% WG at

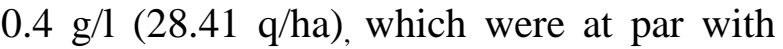
each other. The data on fodder yields in different insecticidal treatments are presented in table 2. All the insecticidal treatments recorded significantly higher fodder yield over untreated control. The highest fodder yield obtained from plot treated with seed treatment of imidacloprid $48 \% \mathrm{FS}$ at $10 \mathrm{ml} / \mathrm{kg}$ seed followed by spray of quinalphos $25 \%$ EC at $2 \mathrm{ml} / \mathrm{l}(66.35 \mathrm{q} / \mathrm{ha})$ and was superior over rest of the treatments. The next best treatment was imidacloprid $48 \%$ FS at $5 \mathrm{ml} / \mathrm{kg}$ seed followed by spray of quinalphos $25 \% \mathrm{EC}$ at 2 $\mathrm{ml} / 1 \quad(58.13 \mathrm{q} / \mathrm{ha})$ and was significantly superior over rest of the treatments. The rest of the treatments were also recorded higher fodder yield over untreated control (31.24 $\mathrm{q} / \mathrm{ha}$ ). The treatments in their descending order of fodder yield were imidacloprid $48 \%$ FS at $10 \mathrm{ml} / \mathrm{kg}$ seed (52.74 q/ha), imidacloprid 48\% 
FS at $5 \mathrm{ml} / \mathrm{kg}$ seed $(51.33 \mathrm{q} / \mathrm{ha})$, quinalphos $25 \% \mathrm{EC}$ at $2 \mathrm{ml} / \mathrm{l}(50.25 \mathrm{q} / \mathrm{ha})$ and thiamethoxam $25 \% \mathrm{WG}$ at $0.4 \mathrm{~g} / 1$ (49.67 $\mathrm{q} / \mathrm{ha}$ ), which were at par with each other. These treatments were followed by imidacloprid $17.8 \% \mathrm{SL}$ at $0.4 \mathrm{ml} / 1(42.84$ $\mathrm{q} / \mathrm{ha})$, fipronil $5 \% \mathrm{SC}$ at $1.5 \mathrm{ml} / \mathrm{l}$ (41.48 q/ha) and azadirachtin $3000 \mathrm{PPM}$ at $5 \mathrm{ml} / \mathrm{l}(39.60$ $\mathrm{q} / \mathrm{ha}$ ), which were at par with each other.

The results obtained from present investigation are in line with results of Pande (2001) reported that the seed treatment with imidacloprid at $15 \mathrm{~g} / \mathrm{kg}$ and thiamethoxam at $10 \mathrm{~g} / \mathrm{kg}$ gave more grain yield of sorghum. Aghav and Sable (2003) observed that the maximum grain yield and fodder yields were obtained from imidacloprid at $1.2 \%$ ST treated plots and closely followed by thiamethoxam at $0.75 \% \mathrm{ST}$. Aghav et al., (2007) reported that maximum grain and fodder yields were obtained from imidacloprid at 1.2 per cent ST treated plots closely followed by thiamethoxam at 0.75 per cent ST.

All these results lend support to the present findings. Hiremath et al., (1995) conducted three successive field trials on seed dresser and soil application for the control of sorghum shoot fly during 1991-92 at Dharwad. They reported that imidacloprid 70 WS as a seed dresser was highly effective in reducing the shoot fly damage $(14 \%)$ and increasing grain yield as compared to soil application of carbofuran granules (40\%) and untreated check $(84 \%)$. The grain yield in respective treatments was 25.0, 18.8 and 7.0 $\mathrm{q} / \mathrm{ha}$. Balikai (1999) reported that the sorghum seed treatment with imidacloprial $70 \mathrm{WS}$ at $10 \mathrm{~g} / 100 \mathrm{~g}$ seed was found most effective with producing highest grain yield of $2.91 \mathrm{t} / \mathrm{ha}$. Wilde et al., (1999) reported the imidacloprid showed direct positive effect on the grain yield of sorghum. Higher yield of sorghum grains has been obtained due to the seed treatment of imidacloprid $70 \mathrm{WS}$ at $10 \mathrm{~g} / \mathrm{kg}$ followed by spray of 5 per cent neem leaf extract at 7 DAE (Anonymous, 2001).

The data in respect of Incremental cost benefit ratio are presented in table 3 . The maximum ICBR of 1:26.77 was obtained in treatment of imidacloprid $48 \%$ FS at $5 \mathrm{ml} / \mathrm{kg}$ seed. The next treatments in their descending order of ICBR were imidacloprid $48 \% \mathrm{FS}$ at $10 \mathrm{ml} / \mathrm{kg}$ seed (1:20.75), imidacloprid 48\% FS at 10 $\mathrm{ml} / \mathrm{kg}$ seed followed by spray of quinalphos $25 \% \mathrm{EC}$ at $2 \mathrm{ml} / \mathrm{l}(1: 12.75)$, imidacloprid $48 \%$ FS at $5 \mathrm{ml} / \mathrm{kg}$ seed followed by spray of quinalphos $25 \% \mathrm{EC}$ at $2 \mathrm{ml} / \mathrm{l}$ (1:11.72), quinalphos $25 \% \mathrm{EC}$ at $2 \mathrm{ml} / \mathrm{l}$ (1:4.91), thiomethoxam $25 \% \mathrm{WG}$ at $0.4 \mathrm{~g} / 1$ (1:4.14), imidacloprid $17.8 \% \mathrm{SL}$ at $0.4 \mathrm{ml} / 1$ (1:3.04) and azadirachtin 3000 PPM at $5 \mathrm{ml} / \mathrm{l}$ (1:2.63). The minimum ICBR was obtained from fipronil 5\% SC at $1.5 \mathrm{ml} / 1$ (1:1.80) (Table 3). These present findings are in agreement with the results of Daware et al., (2012) revealed that the seed treatment with imidacloprid was effective against sorghum shoot fly and recorded highest (1:12.83) Incremental cost benefit ratio.

The maximum net profit of Rs. 24728 obtained from treatment of imidacloprid $48 \%$ FS at $10 \mathrm{ml} / \mathrm{kg}$ seed followed by spray of quinalphos $25 \% \mathrm{EC}$ at $2 \mathrm{ml} / \mathrm{l}$. The next treatments were imidacloprid $48 \%$ FS at 5 $\mathrm{ml} / \mathrm{kg}$ seed followed by spray of quinalphos 25\% EC at $2 \mathrm{ml} / \mathrm{l}$ (Rs.19932). The minimum net profit (Rs. 5940) was obtained from treatment of azadirachtin $3000 \mathrm{PPM}$ at $5 \mathrm{ml} / \mathrm{l}$ (Table 3). It could be interpreted from these result that, although the treatment with imidacloprid $48 \% \mathrm{FS}$ at $5 \mathrm{ml} / \mathrm{kg}$ seed gave maximum ICBR, the net profit over cost of treatment in this treatment (Rs.12848/ha) was less than that obtained from plot receiving imidacloprid $48 \% \quad \mathrm{FS}$ at $10 \mathrm{ml} / \mathrm{kg}$ seed followed by spray of quinalphos $25 \% \mathrm{EC}$ at 2 $\mathrm{ml} / \mathrm{l}$ treatment (Rs. 24728/ha). 


\section{Effect of different insecticidal treatments on natural enemies}

The data on Coccinellids, the population of predatory lady bird beetle, Cheilomenes sexmaculata per plot were recorded on $24^{\text {th }}$ day after emergence and are presented in table 4. The results revealed that there was a significantly higher number of Coccinellids in a plot of untreated control, plots treated with seed treatment and botanical insecticides as compared to spray formulation. The significantly higher surviving populations of Coccinellids recorded in the plot of untreated control (13.00/plot) and it was at par with seed treatment of imidacloprid, $48 \%$ FS at 10 $\mathrm{ml} / \mathrm{kg}$ seed (10.33). The next higher number of Coccinellids were observed in plot treated with seed treatment of imidacloprid $48 \%$ FS at $5 \mathrm{ml} / \mathrm{kg}$ seed (9.33) and was at par with azadirachtin 3000 PPM at $5 \mathrm{ml} / \mathrm{l}$ (9.00). These treatments were significantly superior over rest of treatments. The rest of the treatments in their descending order in respect of Coccinellids population were imidacloprid $17.8 \% \mathrm{SL}$ at $0.4 \mathrm{ml} / 1$ (6.67), thiomethoxam $25 \% \mathrm{WG}$ at $0.4 \mathrm{~g} / \mathrm{l}$ (6.00), imidacloprid $48 \%$ FS at $10 \mathrm{ml} / \mathrm{kg}$ seed followed by spray of quinalphos $25 \% \quad \mathrm{EC}$ at $2 \mathrm{ml} / \mathrm{l}$ (5.00), imidacloprid $48 \% \quad \mathrm{FS}$ at $5 \mathrm{ml} / \mathrm{kg}$ seed followed by spray of quinalphos $25 \% \mathrm{EC}$ at 2 $\mathrm{ml} / \mathrm{l}$ (4.67), fipronil $5 \% \mathrm{SC}$ at $1.5 \mathrm{ml} / 1$ (4.33), quinalphos $25 \% \mathrm{EC}$ at $2 \mathrm{ml} / \mathrm{l}$ (3.67) and were at par with each other.

The present findings are in agreement with the results of Daware et al., (2011) reported that the untreated control plot recorded significantly highest population of lady bird beetle. The biopesticides NSKE $5 \%+0.5 \%$ detergent powder and neemark (azadirachtin $0.03 \%) 50 \mathrm{ml} / 10 \mathrm{l}$ also recorded higher population of lady bird beetle. However, the lowest population was recorded in thiamethoxam $25 \mathrm{WG}$ followed by imidacloprid 17.8 SL.

Table.1 Effect of different insecticidal treatments on plant height

\begin{tabular}{|c|c|c|c|c|}
\hline \multirow{2}{*}{$\begin{array}{l}\text { Tr. } \\
\text { No }\end{array}$} & \multirow[b]{2}{*}{ Treatment } & \multicolumn{3}{|c|}{ Average plant height $(\mathrm{cm})$} \\
\hline & & $21^{\text {th }}$ DAE & $28^{\text {th }}$ DAE & $\begin{array}{c}\text { At } \\
\text { harvest }\end{array}$ \\
\hline $\mathrm{T}_{1}$ & Imidacloprid $48 \% \mathrm{FS}$ at $5 \mathrm{ml} / \mathrm{kg}$ & 49.17 & 56.33 & 194.83 \\
\hline $\mathrm{T}_{2}$ & Imidacloprid $48 \% \mathrm{FS}$ at $10 \mathrm{ml} / \mathrm{kg}$ & 51.67 & 59.83 & 195.67 \\
\hline $\mathrm{T}_{3}$ & $\begin{array}{l}\text { Imidacloprid } 48 \% \mathrm{FS} \text { at } 5 \mathrm{ml} / \mathrm{kg}+ \\
\text { Quinalphos } 25 \% \mathrm{EC} \text { at } 2 \mathrm{ml} / \mathrm{l}\end{array}$ & 50.67 & 57.17 & 204.50 \\
\hline $\mathrm{T}_{4}$ & $\begin{array}{l}\text { Imidacloprid } 48 \% \mathrm{FS} \text { at } 10 \mathrm{ml} / \mathrm{kg}+ \\
\text { Quinalphos } 25 \% \mathrm{EC} \text { at } 2 \mathrm{ml} / \mathrm{l}\end{array}$ & 52.17 & 60.33 & 208.67 \\
\hline $\mathrm{T}_{5}$ & Thiamethoxam $25 \% \mathrm{WG}$ at $0.4 \mathrm{~g} / \mathrm{l}$ & 43.63 & 50.83 & 192.67 \\
\hline $\mathrm{T}_{6}$ & Imidacloprid $17.8 \% \mathrm{SL}$ at $0.4 \mathrm{ml} / 1$ & 39.00 & 44.67 & 182.67 \\
\hline $\mathrm{T}_{7}$ & Fipronil $5 \% \mathrm{SC}$ at $1.5 \mathrm{ml} / \mathrm{l}$ & 35.50 & 43.83 & 181.33 \\
\hline $\mathrm{T}_{8}$ & Quinalphos $25 \%$ EC at $2 \mathrm{ml} / 1$ & 44.17 & 51.67 & 193.17 \\
\hline $\mathrm{T}_{9}$ & Azadirachtin $3000 \mathrm{PPM}$ at $5 \mathrm{ml} / 1$ & 34.50 & 43.33 & 180.83 \\
\hline $\mathrm{T}_{10}$ & Untreated Control & 29.33 & 36.33 & 170.17 \\
\hline & E. \pm & 1.58 & 1.42 & 1.17 \\
\hline & D. at $5 \%$ & 4.70 & 4.23 & 3.47 \\
\hline
\end{tabular}

DAE: Days after emergence 
Table. 2 Effect of different insecticidal treatments on yield of sorghum

\begin{tabular}{|c|c|c|c|}
\hline \multirow{2}{*}{\multicolumn{2}{|c|}{$\begin{array}{ll}\text { Tr. } & \text { Treatment } \\
\text { No. } & \end{array}$}} & \multicolumn{2}{|c|}{ Yield (q/ha) } \\
\hline & & Grain & Fodder \\
\hline $\mathrm{T}_{1}$ & Imidacloprid $48 \% \mathrm{FS}$ at $5 \mathrm{ml} / \mathrm{kg}$ & 29.21 & 51.33 \\
\hline $\mathrm{T}_{2}$ & Imidacloprid $48 \% \mathrm{FS}$ at $10 \mathrm{ml} / \mathrm{kg}$ & 30.15 & 52.74 \\
\hline $\mathrm{T}_{3}$ & $\begin{array}{l}\text { Imidacloprid } 48 \% \mathrm{FS} \text { at } 5 \mathrm{ml} / \mathrm{kg}+\text { Quinalphos } \\
25 \% \mathrm{EC} \text { at } 2 \mathrm{ml} / \mathrm{l}\end{array}$ & 32.43 & 58.13 \\
\hline $\mathrm{T}_{4}$ & $\begin{array}{l}\text { Imidacloprid } 48 \% \mathrm{FS} \text { at } 10 \mathrm{ml} / \mathrm{kg}+ \\
\text { Quinalphos } 25 \% \mathrm{EC} \text { at } 2 \mathrm{ml} / \mathrm{l}\end{array}$ & 34.61 & 66.35 \\
\hline $\mathrm{T}_{5}$ & Thiamethoxam $25 \%$ WG at $0.4 \mathrm{~g} / 1$ & 28.41 & 49.67 \\
\hline $\mathrm{T}_{6}$ & Imidacloprid $17.8 \% \mathrm{SL}$ at $0.4 \mathrm{ml} / 1$ & 26.47 & 42.84 \\
\hline $\mathrm{T}_{7}$ & Fipronil $5 \% \mathrm{SC}$ at $1.5 \mathrm{ml} / 1$ & 26.24 & 41.48 \\
\hline $\mathrm{T}_{8}$ & Quinalphos $25 \% \mathrm{EC}$ at $2 \mathrm{ml} / \mathrm{l}$ & 28.77 & 50.25 \\
\hline $\mathrm{T}_{9}$ & Azadirachtin $3000 \mathrm{PPM}$ at $5 \mathrm{ml} / 1$ & 26.07 & 39.60 \\
\hline $\mathrm{T}_{10}$ & Untreated Control & 23.37 & 31.24 \\
\hline & E. \pm & 0.64 & 1.19 \\
\hline & C.D. at $5 \%$ & 1.91 & 3.53 \\
\hline
\end{tabular}

DAE- Day after emergence

Table.3 Economics of insecticidal treatments used in experiment

\begin{tabular}{|c|c|c|c|c|c|c|c|c|}
\hline $\begin{array}{l}\text { Tr. } \\
\text { No. }\end{array}$ & Treatments & $\begin{array}{l}\text { Quantity of } \\
\text { insecticides } \\
\text { required/ha }\end{array}$ & $\begin{array}{c}\text { Total cost } \\
\text { (Insecticide } \\
\text { + Labour) } \\
\text { (Rs.) (A) }\end{array}$ & $\begin{array}{l}\text { Grain } \\
\text { Yield } \\
\text { (q/ha) }\end{array}$ & $\begin{array}{l}\text { Increase } \\
\text { yield over } \\
\text { control } \\
(\mathrm{q} / \mathrm{ha})(\mathrm{B})\end{array}$ & $\begin{array}{l}\text { Gross } \\
\text { income } \\
\text { (Rs.) } \\
\text { (C) }\end{array}$ & $\begin{array}{c}\text { Net } \\
\text { Profit } \\
\text { (Rs.) } \\
\text { (D) }\end{array}$ & $\begin{array}{c}\text { ICBR } \\
\text { (D/A) }\end{array}$ \\
\hline $\mathrm{T}_{1}$ & $\begin{array}{l}\text { Imidacloprid } 48 \% \mathrm{FS} \\
\text { at } 5 \mathrm{ml} / \mathrm{kg}\end{array}$ & $60 \mathrm{ml}$ & 480 & 29.21 & 5.84 & 64262 & 12848 & $1: 26.77$ \\
\hline $\mathrm{T}_{2}$ & $\begin{array}{l}\text { Imidacloprid } 48 \% \mathrm{FS} \\
\text { at } 10 \mathrm{ml} / \mathrm{kg}\end{array}$ & $120 \mathrm{ml}$ & 720 & 30.15 & 6.78 & 66330 & 14916 & $1: 20.72$ \\
\hline $\mathrm{T}_{3}$ & $\begin{array}{l}\text { Imidacloprid } 48 \% \mathrm{FS} \\
\text { at } 5 \mathrm{ml} / \mathrm{kg}+ \\
\text { Quinalphos } 25 \% \mathrm{EC} \\
\text { at } 2 \mathrm{ml} / 1\end{array}$ & $\begin{array}{c}60 \mathrm{ml}+ \\
11\end{array}$ & 1700 & 32.43 & 9.06 & 71346 & 19932 & $1: 11.72$ \\
\hline $\mathrm{T}_{4}$ & $\begin{array}{l}\text { Imidacloprid } 48 \% \mathrm{FS} \\
\text { at } 10 \mathrm{ml} / \mathrm{kg}+ \\
\text { Quinalphos } 25 \% \mathrm{EC} \\
\text { at } 2 \mathrm{ml} / 1\end{array}$ & $\begin{array}{c}120 \mathrm{ml} \\
11\end{array}$ & 1940 & 34.61 & 11.24 & 76142 & 24728 & $1: 12.75$ \\
\hline $\mathrm{T}_{5}$ & $\begin{array}{l}\text { Thiamethoxam } 25 \% \\
\text { WG at } 0.4 \mathrm{~g} / 1\end{array}$ & $400 \mathrm{~g}$ & 2680 & 28.41 & 5.04 & 62502 & 11088 & $1: 4.14$ \\
\hline $\mathrm{T}_{6}$ & $\begin{array}{l}\text { Imidacloprid } 17.8 \% \\
\mathrm{SL} \text { at } 0.4 \mathrm{ml} / \mathrm{l}\end{array}$ & $400 \mathrm{ml}$ & 2240 & 26.47 & 3.10 & 58234 & 6820 & $1: 3.04$ \\
\hline $\mathrm{T}_{7}$ & $\begin{array}{l}\text { Fipronil } 5 \% \mathrm{SC} \text { at } 1.5 \\
\mathrm{ml} / \mathrm{l}\end{array}$ & 1.51 & 3460 & 26.24 & 2.87 & 57728 & 6314 & $1: 1.80$ \\
\hline $\mathrm{T}_{8}$ & $\begin{array}{l}\text { Quinalphos } 25 \mathrm{EC} \text { at } 2 \\
\mathrm{ml} / \mathrm{l}\end{array}$ & 21 & 2420 & 28.77 & 5.40 & 63294 & 11880 & $1: 4.91$ \\
\hline $\mathrm{T}_{9}$ & $\begin{array}{l}\text { Azadirachtin } 3000 \\
\text { PPM at } 5 \mathrm{ml} / \mathrm{l}\end{array}$ & 51 & 2260 & 26.07 & 2.70 & 57354 & 5940 & $1: 2.63$ \\
\hline $\mathrm{T}_{10}$ & Untreated Control & & & 23.37 & & 51414 & & \\
\hline
\end{tabular}


Table.4 Effect of different insecticidal treatments on predatory Coccinellids and Crossopalpus sp.

\begin{tabular}{|c|c|c|c|}
\hline Tr.No & Treatment & $\begin{array}{c}\text { Population of } \\
\text { Coccinellids /plot }\end{array}$ & $\begin{array}{c}\text { Population of } \\
\text { Crossopalpus sp./plot }\end{array}$ \\
\hline $\mathrm{T}_{1}$ & Imidacloprid $48 \% \mathrm{FS}$ at $5 \mathrm{ml} / \mathrm{kg}$ & $9.33(3.13)$ & $4.33(2.20)$ \\
\hline $\mathrm{T}_{2}$ & Imidacloprid $48 \% \mathrm{FS}$ at $10 \mathrm{ml} / \mathrm{kg}$ & $10.33(3.29)$ & $4.66(2.27)$ \\
\hline $\mathrm{T}_{3}$ & $\begin{array}{l}\text { Imidacloprid } 48 \% \text { FS at } 5 \mathrm{ml} / \mathrm{kg} \\
+ \text { Quinalphos } 25 \% \text { EC at } 2 \mathrm{ml} / \mathrm{l}\end{array}$ & $4.67(2.26)$ & $2.00(1.56)$ \\
\hline $\mathrm{T}_{4}$ & $\begin{array}{l}\text { Imidacloprid } 48 \% \mathrm{FS} \text { at } 10 \mathrm{ml} / \mathrm{kg} \\
+ \text { Quinalphos } 25 \% \mathrm{EC} \text { at } 2 \mathrm{ml} / \mathrm{l}\end{array}$ & $5.00(2.34)$ & $2.00(1.56)$ \\
\hline $\mathrm{T}_{5}$ & Thiamethoxam $25 \% \mathrm{WG}$ at $0.4 \mathrm{~g} / 1$ & $6.00(2.54)$ & $2.33(1.68)$ \\
\hline $\mathrm{T}_{6}$ & Imidacloprid $17.8 \% \mathrm{SL}$ at $0.4 \mathrm{ml} / \mathrm{l}$ & $6.67(2.67)$ & $2.33(1.68)$ \\
\hline $\mathrm{T}_{7}$ & Fipronil $5 \% \mathrm{SC}$ at $1.5 \mathrm{ml} / \mathrm{l}$ & $4.33(2.18)$ & $1.66(1.46)$ \\
\hline $\mathrm{T}_{8}$ & Quinalphos $25 \%$ EC at $2 \mathrm{ml} / 1$ & $3.67(2.03)$ & $1.33(1.34)$ \\
\hline $\mathrm{T}_{9}$ & Azadirachtin $3000 \mathrm{PPM}$ at $5 \mathrm{ml} / \mathrm{l}$ & $9.00(3.08)$ & $4.00(2.11)$ \\
\hline \multirow[t]{3}{*}{$\mathrm{T}_{10}$} & Untreated Control & $13.00(3.67)$ & $7.00(2.73)$ \\
\hline & S.E. \pm & 0.15 & 0.13 \\
\hline & C.D. at $5 \%$ & 0.43 & 0.38 \\
\hline
\end{tabular}

*Figures in parentheses are square root transformed values, DAE- Day after emergence

Balikai (2007) revealed that the plant products viz., Catheranthes rosea L. leaves at 5\%, Azadirachta indica kernels at 5\% and Pongemia pinnata $\mathrm{L}$. kernels at $2 \%$ were safe to natural enemies in rabi sorghum.

The data on the population of dipteran predator Crossopalpus sp. per plot recorded on $24^{\text {th }}$ day after emergence and are presented in table 4 . The results revealed that there was significantly higher number of Crossopalpus sp. in a plot of untreated control, plots treated with seed treatment and botanical insecticides as compared to spray formulation. The significantly higher surviving population of Crossopalpus sp. recorded in the plot of untreated control (7.00/plot).

The next higher number of Crossopalpus sp. were observed in plots treated with seed treatment of imidacloprid $48 \% \mathrm{FS}$ at $10 \mathrm{ml} / \mathrm{kg}$ seed (4.66), imidacloprid $48 \%$ FS at $5 \mathrm{ml} / \mathrm{kg}$ seed (4.33) and azadirachtin 3000 PPM at $5 \mathrm{ml} / 1$ (4.00) and were at par with each other. These treatments were significantly superior over rest of the treatments. The rest of the treatments in their descending order in respect of Crossopalpus sp. population were imidacloprid $17.8 \% \mathrm{SL}$ at $0.4 \mathrm{ml} / 1$ (2.33), thiamethoxam
$25 \% \mathrm{WG}$ at $0.4 \mathrm{~g} / \mathrm{l}(2.33)$, imidacloprid $48 \% \mathrm{FS}$ at $10 \mathrm{ml} / \mathrm{kg}$ seed followed by spray of quinalphos $25 \% \quad \mathrm{EC}$ at $2 \mathrm{ml} / \mathrm{l}$ (2.00), imidacloprid $48 \%$ FS at $5 \mathrm{ml} / \mathrm{kg}$ seed followed by spray of quinalphos $25 \% \mathrm{EC}$ at $2 \mathrm{ml} / \mathrm{l}$ (2.00), fipronil $5 \% \mathrm{SC}$ at $1.5 \mathrm{ml} / \mathrm{l}$ (1.66) and quinalphos $25 \% \mathrm{EC}$ at $2 \mathrm{ml} / \mathrm{l}(1.33)$ and were at par with each other. Thus, the results obtained revealed that the seed treatment of imidacloprid $48 \%$ FS and spray of azadirachtin 3000 PPM were the less toxic and most safer treatments to predatory Coccinellids and Crossopalpus sp. population. Pawar et al., (2009) observed that the maximum population of Crossopalpus sp., a dipteran predator was recorded in untreated control (3.4 adults /plant), while treatment shoot clipping recorded 3.0 adults /plant and NSKE at 4\% recorded 2.8 adults /plant. Singh and Sharma (2002) reviewed the current status of information on diversity, ecobiology, parasitism levels and mass rearing of the parasitoids, predators and pathogens attacking different stages of sorghum shoot fly, Atherigona soccata.

The present study provided useful information on detrimental effect of insecticides on natural enemies revealed that the seed treatment of imidacloprid $48 \%$ FS $10 \mathrm{ml} / \mathrm{kg}$ and spray of 
azadirachtin 3000 ppm found effective. Maximum incremental cost benefit ratio was obtained in treatment of imidacloprid $48 \%$ FS at $5 \mathrm{ml} / \mathrm{kg}$ seed. The maximum net profit, plant height and yield of sorghum were obtained in the treatment imidacloprid $48 \%$ FS at $10 \mathrm{ml} / \mathrm{kg}$ seed followed by spray of quinalphos $25 \%$ EC at $2 \mathrm{ml} / \mathrm{l}$.

\section{References}

Aghav, S.T. and Sable, K.R. 2003. Evaluation of different insecticides against shoot fly, Atherigona soccata (Rondani) infesting sorghum. State level seminar on pest management of sustainable agriculture. MAU, Parbhani, M.S., India. Pp. 52-54.

Anonymous. 2012. Annual Report for 2011-12, All India Coordinated Sorghum Improvement Project, NRC on Sorghum Hyderabad, India.

Balikai, R.A. 1999. Bioefficacy of imidacloprid $70 \mathrm{WS}$ on sorghum shoot fly, Atherigona soccata (R). Insect Environ., 5(1): 43.

Balikai, R.A. 2000. Bio-efficacy of imidacloprid 70 WS against sorghum shoot fly in rabi season. Res. crops, 1(2): 192-195.

Balikai, R.A. and Bhagwat, V.R. 2009. Evaluation of integrated pest management components for the management of shoot fly, shoot bug and aphid in rabi sorghum. Karnataka J. Agric. Sci., 22(3): 532-534.

Kandalkar, H.G. and Narkhede, S.S. 1989. Synthetic pyrethroids and plant extracts against sorghum shoot fly. Pesticides, 23(4): 24.

Karibasavaraja, Balikai, L.R. and Deshpande, V.P. 2005. Thiamethoxam $70 \mathrm{WS}$, a new promising seed dresser for the suppression of sorghum shoot fly. Ann. Pl. Protec. Sci., 13(1): 85-87.

Kudale, N.V. 2002. Evalution of new systemic insecticides against Atherigona soccata (Rondani) and Chilo partellus (Swinhoe) on sorghum. M.Sc. (Agri.) Thesis, Dr. PDKV, Akola, M.S., India.

Kumar, L.V. and Prabhuraj, A. 2007. Bioefficacy of chemicals for seed treatment against sorghum shoot fly (Atherigona maidis). Ann. Pl. Protec., Sci., 15(2): 312- 315.

Mote, U.N. 1993. A new insecticide imidacloprid as seed dresser for the control of sorghum shoot fly. Pestol., 17(1): 23-26.

Mote, U. N., Mohite, A.P. and Lolge, G.R. 1995. Effect of imidacloprid as seed dresser and foliar spray against sorghum shoot fly. Pestol., 19(5): 24-28.

Naitam, N.R. and Sukhani, T.R. 1985. Oviposition behavior of sorghum shoot fly A. soccata (Rondani) under different soil, plant, weather parameters. Indian J. Ent., 47 (2): 195-200.

Pawar, V.M., Jadhav, G.D. and Kadam, B.S. 1984. Bioefficacy of Oncol 40 EC, Carbofuran $3 \mathrm{G}$ and Carbofuran $50 \mathrm{SP}$ against sorghum shoot fly. Pesticides, 18(8): 44-46.

Pande, N.G. 2001. Management of sorghum shoot fly with the seed treatment of some insecticides. M.Sc. (Agri.) Thesis, Dr. PDKV, Akola, M.S., India.

Reddy, K.V. and Davies, J.C. 1979. Pests of sorghum and pearl millet and their parasitoids and predator recorded at ICRISAT center up to August, 1979. Cereal Entomology Progress Report 2. Patancheru, India, pp 58-61.

Sharma, Manorama, Kapoor, K.N. and Bharaj, G.S. 1996. Effect of seed treatment of sorghum with some new insecticides for control of shoot fly. Crop Res., 11(1): 9092.

Sable, K.R., Karanjkar, R.R. and Ingle, V.R. 2003. Use of different plant extracts for the control of sorghum shoot fly, Atherigona soccata $(\mathrm{R})$. State level seminar sustainable agriculture. M.A.U. Parbhani, M.S., India, pp
184-186.

\section{How to cite this article:}

Birangal, A.B., K.S. Pagire, B.M. Wagh and Dipali Thakare. 2017. Performance of Newer Insecticidal Treatments on Natural Enemies and Yield Contributing Factors in Sorghum. Int.J.Curr.Microbiol.App.Sci. 6(2): 416-423. doi: http://dx.doi.org/10.20546/ijcmas.2017.602.046 